\title{
REVERSE LOGISTICS IN THE ASPECT OF WEEE AND RoHS REGULATIONS
}

\author{
Aleksandra Nowakowska, MSc, anowa@zim.pcz.pl \\ Czestochowa University of Technology, Management Faculty \\ L'ubomir Jahnatek, PhD \\ Ministry of Economy of the Slovak Republic
}

\begin{abstract}
Recent years have seen a growing importance of reverse logistics. The reasons for this include increased ecological awareness as well as the strategy and policy of companies and ever-increasing number of legal regulations which force companies to accept returns of faulty products and to manage them so as to minimize harmful effect on natural environment. Due to this reason, companies must begin development of reverse distribution systems in order to deal with influx of faulty and damaged product or products after recycling.
\end{abstract}

\section{Fundamental aspects of reverse logistics}

In the subject literature four principles in relation to reverse logistics might be indicated, ordered according to their priority ${ }^{1}$. They include:

- using of recycled materials for production, at the cost of new materials,

- using ecological materials,

- reuse of recycled materials (mainly packaging),

- recovery of materials and worn-out products.

However, these activities are often expensive and require additional efforts from companies, which is neither desirable nor commonly used. As early as in the stage of design of products the requirements for re-use of waste, mainly from the point of view of cost-effectiveness should be taken into consideration. Activities of reverse logistics result in particular consequences for all company's production-related activities. If a life cycle of ready products is analysed, along with the impact of environmental factors on production process, use by the customer and disposal of products, it will become possible to design such products which are easy to be disassembled and passed to recovery. The manufacturers will be forced to cooperate with suppliers and their subcontractors so that they deliver materials and components which are suitable to be reused.

An example of the system solutions possible to be employed might be a policy adopted in relation to packaging. ${ }^{2}$ It is an essential issue from the point of view of reverse logistics. If the route of packaging is analysed from the moment of completion of its fundamental task, i.e. protection of goods, one can see that the locations of waste generation are scattered and there is a lack of determined rules which would explain the principles of their appearance. This creates the problems with their re-use. Typical characteristics of the networks of products' recovery contain a convergent part of amassing and transport from the disposal market to the recovery unit and

\footnotetext{
${ }^{1}$ Wu H.J., DunnS.C.: Environmentally Responsible Logistics Systems, „International Journal of Distribution \& Logistics Management" 1995, No. 25(2), p.20-39f

${ }^{2}$ Krawczyk S.: Zarządzanie procesami logistycznymi (Management of Logistics Processes), PWE, Warsaw, 2001, p.291-292
} 
divergent part for the distribution to the re-use market as well as the middle part connected with the required stages of recovery process. Moreover, they derive from typical types of networks through recovery options, where the networks differ for recycling materials, processing, reuse components, re-packaging, warranty and commercial returns. These types of networks vary in relation to types of networks, their role and cooperation between their participants, systems of determination of their use. Thus, environmental aspect might impact on type of networks, their role and cooperation between participants and system of determination of the method of use. It is commonly recommended that the entities which produce goods should be located in possibly closest distance from end users. Such a policy enables unconstrained direct deliveries of worn-out products from end users to manufacturers.

\section{Legal solutions and their impact on activities of reverse logistics}

In operation of companies in common European Union market one can highlight particular limitations in implementation of common policy in relation to waste. This results mainly from the fact of lack of such common policy. Obviously, each EU country have their own procedures and standards on that issue, however, they are not standardized for all the member states of the Fifteen. Currently the companies must continue preparations to ever-increasing environmental regulations and management of hazardous substances since EU regulations of WEEE and RoHS assume that it is manufacturers who are responsible for final disposal of any electronic equipment which is sold by them, and this indicates direction of organization of reverse logistics. The issue of products retired from sales is currently considered not only theoretically: this has become a normal procedures of manufacturers of industrial and consumer goods.

European directive on Restriction of Hazardous Substances (2002/95/EC), on 27 January 2003, in force since 1 July 2006 is supposed to limit use of hazardous substances in electronic and electrical equipment and to ensure health and environment protection through appropriate recycling of such equipment. The directive assumes that new electronic equipment implemented in the territory of the European Union after 1 July 2006 must not contain harmful materials: lead, mercury, cadmium, hexavalent chromium, polybrominated biphenyls (PBBs) or polybrominated diphenyl ethers (PBDE) The maximal permissible amounts of these substances in elements and equipment where defined where the presence of these substances can not be eliminated - e.g. mercury in fluorescent lamps or lead additions in glass. Reduction of lead contents in computer system components is supposed to last until 2010. The RoHS directive derives immediately from other EU directive, WEEE (Waste from Electrical and Electronic Equipment), i.e. the waste directive, and they are strictly related to each other. Both directives are supposed to reduce waste from electrical and electronic products while elimination of risk of pollution of natural environment. After 1 July 2006, each end product, subject to the directive and implemented into European market has to meet the requirements of RoHS directive. This concerns products imported into the European Union and the products designated to sales, manufactured within the European Union. The scope of RoHS encompasses finished products but do not concern elements and semi-finished products being the components of the final product. In practice, manufacturers will need the components complying to RoHS directive so that the final products meets the requirements of the directive. The products under the RoHS directive include:

- large-size household equipment,

- small-size household equipment, 
- IT and telecommunications equipment,

- consumer equipment,

- lighting equipment,

- electronic and electrical devices (except for large-size, stationary industrial devices),

- toys, recreational and sport equipment,

- automated machines.

The RoHS directive concerns European Union markets, however, it has immediately become a standard throughout world markets due to globalization of electronic market. Similar initiatives, conditioned by RoHS directive are implemented in many countries which are not the European Union members. The appropriate implementation of the RoHS directive is supervised by the execution body, which may undertake steps necessary to assessment of properly fulfilled requirements of the directive by the manufacturers. Any discrepancies may lead to penalty as well as to total retiring of the product from EU market. The directive contains several concessions on limitation of use of hazardous substances due to lack of technical possibilities to replace such substances. Main exceptions include lead and mercury.

Lead may be used for:

- $\quad$ solder alloys with high melting point ( $>85 \%$ of lead)

- piezoelectric materials,

- kinescope glass,

- alloys defined by the directive

- While mercury:

- fluorescent lamps and other types of lamps.

The directive also permits, under special conditions, use of cadmium processing and application of hexavalent cadmium. In case of special applications, the European Union may conditionally permit other harmful substances, however, the permission is granted only temporarily ${ }^{3}$. There are no standards which condition marking of the elements in accordance with RoHS, although the manufacturers implemented their own systems of marking in order to facilitate unambiguous identification of the products by the customers. It is remarkable that the directive has impact not only on manufacturers and procurement companies, but also on logistics, quality control, inventory, supplies or on the final customer. RoHS has also influence on products which are not directly defined within this directive since manufacturers should forecast various use of their products by the final user, whose protection became the aim of the RoHS directive. The EU do not require any particular declaration of conformity with RoHS directives, however, customers may require delivery of the documents proving such a conformity with a form to be filled in or with entire documentation.

The manufactures prefer, however, only to add information about conformity or about lack of it. It is also common practice that the elements subject to RoHS directive are marked on bulk and individual containers and packages, in invoices or bills of consignment. There are also the markings by manufacturers such as green or PB free. These markings are not in accordance with RoHS directive. First one means only the limitation in using harmful substances, not adapted to process of lead-free soldering (higher soldering temperature), while the latter means

\footnotetext{
${ }^{3}$ List of all changes can be find in the Commission Decision No. 2005/747/WE.
} 
products with eliminated lead. The limitations of use of harmful substances is followed by the necessity of implementation of new, more expensive metals and their compounds during the production process. The process itself will be also changed so as it can be adapted to production in accordance with RoHS. All the changes involve quite considerable rise in costs of manufacturing of products in accordance with the directive. Full conformity with RoHS requires not only limitation of the substances forbidden by the directive, but also adaptation of elements to the process of lead-free soldering, i.e. preparation of the element for use of higher soldering temperatures. Sadly, lead-free solder alloys melt at the temperatures higher by about $40^{\circ} \mathrm{C}$ than lead alloys. This enlarges the time of soldering, which negatively impacts on the quality of the solder. Possible alternative to that issue are electricity conducting glues, however, currently they are not commonly used.

The directive of RoHS is closely related to WEEE directive (Waste of Electrical and Electronic Equipment), whose aim is to minimize negative impact of electronic waste on environment. This directive imposes responsibility on producers, suppliers and importers for collection, reuse and recycling and recovery of electronic waste.

The waste is subdivided into various categories and for each of them the different principles of recycling have been defined.

Products which are subject to WEEE directive include:

large-size household equipment,

small-size household equipment,

- IT and telecommunications equipment,

- consumer equipment,

- lighting equipment,

- electronic and electrical devices (except for large-size, stationary industrial devices),

- toys and sport equipment,

- medical equipment (except implanted and infected products),

- monitoring and control equipment,

- automated machines.

The standards of the directive must be met by the companies and individuals who:

- manufacture or sell electronic and electrical equipment under their trademark,

- resell equipment produced by other party under their trademark,

- import or export electrical or electronic equipment to member states in the EU.

\section{Current situation in recovery and management of worn-out electrical and electronic equipment in Poland in 2006}

Considering assumptions for common policy in terms of management of worn-out electronic and electrical products, one can observe some relationships presented by Główny Inspektorat Ochrony Środowiska (Main Inspectorate of Environmental Protection) in Poland in 2006. The comparison is presented in the Table 1

\begin{tabular}{|l|l|l|l|}
\hline $\begin{array}{l}\text { Number and name of the } \\
\text { group of the equipment } \\
\text { which turned into a worn- } \\
\text { out equipment }\end{array}$ & $\begin{array}{l}\text { Total weight of the } \\
\text { equipment }\end{array}$ & $\begin{array}{l}\text { Total weigh of collected } \\
\text { worn-out equipment }\end{array}$ & $\begin{array}{l}\text { Level of collected worn- } \\
\text { out equipment }\end{array}$ \\
\hline & $\mathrm{Kg}$ & $\mathrm{kg}$ & $\%$ \\
\hline large-size household & 131625527 & 1415055 & \\
\hline
\end{tabular}




\begin{tabular}{|c|c|c|c|}
\hline equipment & & & 1,08 \\
\hline $\begin{array}{l}\text { small-size household } \\
\text { equipment }\end{array}$ & 16895404 & 134840 & 0,80 \\
\hline $\begin{array}{l}\text { IT and telecommunications } \\
\text { equipment }\end{array}$ & 38017133 & 1580629 & 4,16 \\
\hline audio/video equipment & 34078682 & 672114 & 1,97 \\
\hline lighting equipment & 15531496 & 931364 & 6,00 \\
\hline $\begin{array}{l}\text { electronic and electrical } \\
\text { devices (except for large- } \\
\text { size, stationary industrial } \\
\text { devices) }\end{array}$ & 13849849 & 232858 & 1,68 \\
\hline toys and sport equipment & 3391534 & 19460,5 & 0,57 \\
\hline $\begin{array}{l}\text { medical equipment (except } \\
\text { implanted and infected } \\
\text { products) }\end{array}$ & 2189188 & 21675,5 & 0,99 \\
\hline $\begin{array}{l}\text { monitoring and control } \\
\text { equipment }\end{array}$ & 1222449 & 16445 & 1,34 \\
\hline automated machines & 924827 & 6748,5 & 0,73 \\
\hline Total & 257726091 & 5031189,5 & 1,95 \\
\hline
\end{tabular}

Source: Report of Main Inspectorate of Environmental Protection on functioning of the system of management of worn-out electrical and electronic equipment in 2006.

Comparison in the Table No.1 indicates that a percentage of the collected equipment is still insignificant. The biggest group is lightning equipment and IT and telecommunication equipment, however, this means barely a few percent. The data, on the basis of which the analysis has been made, concern only the period of second half of 2006 ( $3^{\text {rd }}$ and $4^{\text {th }}$ quarter); it is remarkable that 2006 was the first year of implementation of the system of management of wornout equipment, and not all the manufacturers, who were obliged to register within the Main Inspectorate of Environmental Protection (GIOŚ), registered within the deadline and thus they did not send to GIOŚ relevant reports or the reports were incomplete ${ }^{4}$. Taking these aspects into consideration one can assume that two nearest years will show how Polish companies adapt their activities to legal solutions currently in force in the European Union, also becoming more popular worldwide, concerning collection and processing of waste. According to the Report, recovery and processing of equipment is currently of minor nature, however, in upcoming years a rapid development of the management of worn out electrical and electronic equipment and subordination of the entrepreneurs to current law might be expected.

\footnotetext{
${ }^{4}$ Report of Main Inspectorate of Environmental Protection on functioning of the system of management of worn-out electrical and electronic equipment in 2006.
} 
The presented investigations show, that in line with adaptation of the procedures for waste management and its common application, new problems will arise; the companies will have to face these problems and use reverse logistics solutions on a larger scale than they did before. For instance, it will become necessary to determine locations of acceptance, storage and processing of worn-out equipment, methods of its identification, coding, transport, classification according to its destination (recycling, repairs, re-use of components etc.). Improvement in activities connected with this tasks will be possible through employing solutions of reverse logistics.

\section{Bibliography:}

1. Krawczyk S.: Zarządzanie procesami logistycznymi (Management of Logistics Processes), PWE, Warsaw, 2001, p.291-292

2. List of all changes can be find in the Commission Decision No. 2005/747/WE.

3. Report of Main Inspectorate of Environmental Protection on functioning of the system of management of worn-out electrical and electronic equipment in 2006.

4. Wu H.J., DunnS.C.: Environmentally Responsible Logistics Systems, „International Journal of Distribution \& Logistics Management" 1995, No. 25(2), p.20-39f 